\title{
Estudos gramaticais à luz da linguística ecossitêmica
}

\author{
Hildo Honório do Couto*
}

\begin{abstract}
Resumo
O objetivo deste artigo é apresentar argumentos em prol de uma representação reticular-rizomática do que a tradição tem chamado de estrutura linguística, tendo por base teórica a versão da ecolinguística chamada de linguística ecossistêmica. Para tanto, ele apresenta um panorama das concepções de língua ao longo da história, salientando que as primeiras concepções laicas estavam em consonância com a ciência moderna, mas que as primeiras reflexões sobre questões linguísticas eram normativas, pressupunham um sistema estático. As primeiras tentativas de se representar graficamente se deram no âmbito semântico e fonético-fonológico. Na sintaxe, uma das primeiras formas de representação deve ter sido a do estruturalista Lucien Tesnière e a dos constituintes imediatos do estruturalismo norte-americano. A concepção de língua como esqueleto dos primeiros "filólogos" continuou e foi aperfeiçoada no estruturalismo e na gramática gerativa, que ficam no nível da ciência da mecânica de Newton e da filosofia de Descartes. Foi com a gramática estratificacional, agora linguística neurocognitiva, que as representações começaram a dar conta da língua como fenômeno dinâmico, não unilinear e unidirecional. Após as visões de língua como organismo e como vírus, respectivamente, surgiu a visão ecossistêmica de língua, segundo a qual ela é basicamente interação e suas representações devem ser do tipo redes ou rizomas multidirecionais e multilaterais. Enfim, esta última representação contém as demais em seu interior, é mais ampla do que elas.

Palavras-chave: Estrutura. Redes. Rizoma. Ecolinguística. Linguística ecossistêmica.
\end{abstract}

\section{Introdução}

A linguística ecossistêmica, ramo da ecolinguística brevemente apresentado na seção seguinte, é um novo modo de se estudarem os fenômenos da linguagem que vem emergindo no contexto da também jovem ecolinguística. Por esse motivo, os estudos de questões gramaticais e de estrutura em geral ainda são bastante incipientes. O que vou apresentar aqui são as primeiras tentativas de se tratar dessas questões. Na década de setenta, Sydney Lamb propôs a chamada gramática estratificacional, hoje linguística neurocognitiva, cujo tratamento das estruturas

* Professor do Programa de Pós-graduação em Linguística - Universidade de Brasília (UnB). 
linguísticas já ia parcialmente na direção da visão ecossistêmica. Infelizmente, porém, a gramática gerativa proposta na mesma época ofuscou esse interessante modelo teórico, devido ao grande prestígio de Noam Chomsky. Foi uma pena, pois a proposta de Lamb estava muito mais em sintonia com a nova visão de mundo iniciada pela teoria da relatividade do que a de Chomsky, que lembra mais a mecânica clássica de Newton.

A representação dos fenômenos linguísticos depende inteiramente do modelo teórico empregado. O modelo teórico, por seu turno, está atrelado à concepção filosófica de língua em que se baseia. Por isso, passarei em revista, perfunctoriamente, as diversas concepções de língua e respectivas representações ao longo da história, embora não obedecendo necessariamente uma sequência cronológica. Mesmo porque, como veremos, há sobreposições, avanços e recuos entre elas.

As seções de 1 a 7 deste artigo são uma preparação para o que está discutido na seção 8 , a concepção de representação dos fenômenos da língua como uma rede orgânica de interações, não como uma estrutura. Isso vale tanto para a endoecologia quando para a exoecologia linguística.

\section{Ecolinguística e Linguística Ecossistêmica}

Na esteira do pioneiro Haugen (1972), a ecolinguística vem sendo definida como o estudo das interações entre língua e meio ambiente sendo que, para o autor, meio ambiente da língua é a sociedade. Com o advento da vertente chamada linguística ecossistêmica, notou-se que essa conceituação é insuficiente. Como o ecossistema é o conceito central da ecologia, deve-se procurar pelo seu equivalente no estudo dos fenômenos da linguagem, o ecossistema linguístico. Tal qual no ecossistema biológico, ele consta de uma população ou um povo $\left(\mathrm{P}_{1}\right)$, cujos membros convivem em determinado lugar, seu território $\left(\mathrm{T}_{1}\right)$, interagindo entre si pelo modo natural de interagir localmente, a língua $\left(\mathrm{L}_{1}\right)$ em seu aspecto natural. Mais especificamente, este é o ecossistema natural da língua, no interior do qual $\mathrm{P}_{1} \mathrm{~T}_{1}$ constitui o meio ambiente natural da língua. Mas, a língua é formada, armazenada e processada no cérebro de cada falante da comunidade. Portanto, ele é o locus das interações mentais, o "território" $\left(\mathrm{T}_{2}\right)$ em que elas se dão. Essas interações, ou seja, as conexões neurais constituem, segundo António Damásio, a mente, que é a parte ativa, existente em cada indivíduo da comunidade, logo, $\mathrm{P}_{2}$. 
As próprias interações constituem a língua como fenômeno mental $\left(\mathrm{L}_{2}\right)$. Cérebro, mente e língua como fenômeno mental constituem o ecossistema mental da língua. No caso, o meio ambiente mental da língua é $\mathrm{P}_{2} \mathrm{~T}_{2}$. Mas, para a maioria dos estudiosos, a língua é um fenômeno social.

O ecossistema social da língua é constituído por uma coletividade de indivíduos como seres sociais, ou seja, o lado $\mathrm{P}_{3}$ desse ecossistema. O locus, o "território" das interações entre esses seres sociais é a sociedade $\left(\mathrm{T}_{3}\right)$. As interações são a própria língua como fenômeno social $\left(\mathrm{L}_{3}\right)$. $\mathrm{P}_{3} \mathrm{~T}_{3}$ é o meio ambiente social da língua, como queria Haugen. Encarando a língua holisticamente, temos ainda o ecossistema integral da língua, que abrange os outros três. Enfim, a língua não é apenas social, mental ou natural. Ela é as três coisas ao mesmo tempo, ou seja, é biopsicossocial (cf. COUTO, 2007).

É no contexto do ecossistema integral da língua que se indaga pelas questões fundamentais: se ela é uma realidade natural (biológica), como quer a biolinguística; se mental ou social; se há uma "gramática universal", se é que isso faz sentido. Já que ecossistema linguístico é o mesmo que comunidade linguística, é aqui também que se estabelece a distinção entre comunidade de língua versus comunidade de fala, que não dá para discutir aqui (ver COUTO, 2015).

A ecolinguística em geral está muito bem exposta em, entre outros, Fill (1993, 1996) e Makkai (1993). A linguística ecossistêmica vem sendo apresentada em Finke (1996), Trampe (1990) e Couto (2015). Em Couto; Couto; Araújo; Albuquerque (2016) há diversos textos sobre as duas. A seguir, discutirei as diversas maneiras pelas quais a língua tem sido encarada ao longo da história.

\section{Língua como esqueleto I}

A visão de língua como algo inerte, uma espécie de esqueleto, começa na Antiguidade, assim que surgiram filólogos ditando normas de bem falar e bem escrever, logo, partindo de um padrão que eles consideravam o ideal, e padrão é um tipo de sistema. Obviamente, não havia esquemas para representação dos dados. Isso aconteceu também nos primeiros trabalhos linguísticos, tanto no Ocidente quanto no Oriente.

No mundo ocidental, a natureza era vista como um livro escrito por Deus, durante toda a Idade Média, livro que devia ser interpretado; logo, ela era algo feito, que estava lá para ser decifrado. Na Renascença, ela passou a ser encarada como 
reflexo do corpo humano, que era um microcosmo que refletia o macrocosmo. Vale dizer, ela era um organismo, mesmo que um organismo isolado do resto do mundo. Do Iluminismo em diante, ela passou a ser vista como uma máquina. Primeiro como um relógio (século XVII), depois como um barco a vapor e, nos dias atuais como um computador. A concepção de língua teve aproximadamente o mesmo percurso da visão da natureza. Assim, a visão cartesiana teve continuidade no homme machine de La Mettrie, no século XVIII. É nesse contexto que surgiu a "Grammaire générale et raisonnée de Port Royal" (1660), de base filosófica cartesiana. Essa concepção de língua e mundo veio a ser a principal base filosófica para a gramática gerativa atual. A metáfora do computador está presente nas reflexões de seu criador, Noam Chomsky, que, por exemplo, fala em componente lexical e computacional da língua.

Como se deduz de Coseriu (1980: 2-3), desde a Antiguidade, passando pela Idade Média e o Renascimento até o século XVIII, a linguística tem visto a língua como um esqueleto (estrutura), cuja anatomia era preciso dissecar. No século XIX, essa concepção continuou, mesmo que o objeto a dissecar tenha passado a ser encarado como um organismo (Schleicher e todos os comparatistas). Como se pode notar, há uma discrepância no que se refere ao início e final de cada período. No entanto, a tendência geral permanece. É claro que houve investigadores isolados que viam a língua como algo dinâmico, como o catalão Juan Luis Vives (1492-1540). No entanto, eles foram a exceção que confirmava a regra. Mesmo assim, ainda não havia tentativas de representar graficamente esse esqueleto ou esse organismo.

No Oriente, temos as minuciosas pesquisas fonéticas de Panini (cerca do século V-IV a.C.), na Índia. Na China, as primeiras inscrições de ideogramas em ossos oraculares recuam a quinze séculos. No entanto, as explicações mais sistemáticas sobre a origem e o uso deles datam aproximadamente do século VIII a.C. (AMMIROVA et al., 1980: 64). Essa visão normativa tinha o mesmo objetivo dos primeiros filólogos ocidentais: estabelecer regras de bem falar, melhor, de bem escrever, manter e monitorar a observância das respectivas regras. Isso significa que todas essas tradições partiam de um sistema, de algo como um esqueleto inerte, que não podia mudar.

Em suma, "a essência das teorias linguísticas da Antiguidade consiste em fornecer regras para o uso da língua, que deve ser encarada como o resultado de uma nomeação prévia de objetos. Essa nomeação forma ao fim e ao cabo a 
estrutura de uma língua humana. Às regras de nomeação dá-se o nome de arte de gramática ou arte de escrever" (AMMIROVA et al., 1980, p, 36).

Uma das primeiras tentativas, se não a primeira, de representar fenômenos da linguagem esquematicamente surgiram no âmbito da fonética. Tentativas de representar as vogais, por exemplo, recuam pelo menos ao início do século XII. No entanto, a primeira representação que obteve sucesso foi a de Christoph Hellwag (1781). Ele tentou representar a topologia dos sons no trato bucal, no que até hoje é chamado de "triângulo de Hellwag". Curiosamente, não apareceu nenhuma sugestão de representar graficamente o esqueleto sintático nem o morfológico da língua. No âmbito da semântica, a representação das preposições de movimento de Wilkins (1614-1672) aparentemente é a primeira tentativa de mostrar em gráficos ou figuras as relações que elas representam. Na linguística ecossistêmica, a ecologia das relações espaciais das preposições tem sido estudada há já algum tempo, como se pode ver em Couto (2010).

Ainda no que tange à fonética, Daniel Jones propôs uma representação trapezoidal das vogais, em 1917, no contexto da Associação Fonética Internacional (IPA, pela sigla em inglês). Essa representação e a triangular foram incorporadas definitivamente nos estudos linguísticos, mais especificamente, nos fonéticofonológicos.

\section{Língua como esqueleto II}

Com o advento do estruturalismo, a ideia de língua como estrutura estática ganhou novo impulso. Após as obras pioneiras de Saussure na Europa e Bloomfield nos Estados Unidos, surgiram vários modelos estruturalistas, ao lado da continuidade dos estudos fonéticos em torno da IPA. Na Europa, uma das primeiras propostas para se representar a estrutura sintática foi a de Lucien Tesnière (1893-1954). Sua pesquisa dos anos 40 e 50 culminaram com a publicação póstuma de "Éléments de syntaxe structurale", em 1959. É a gramática da dependência, que via no verbo o centro da estrutura e tudo o mais dependente dele. Ele era a forma governante; as demais eram formas governadas, na estrutura do estema (gráfico).

Tesnière avançou diversas ideias adotadas pouco depois pela gramática gerativa, como a independência da sintaxe - com frases gramaticais, mas sem sentido como "O silêncio vertebral indispõe a vela lícita”. Ele comparava o esquema de uma oração como "o menino vê a menina" a um drama, uma peça teatral, com seus actantes e 
circunstantes, tudo em torno de uma ação. Enfim, sua gramática de dependência é mais interessante do que a da gramática de constituintes do estruturalismo e do gerativismo, pois está mais próxima da visão do mundo como uma imensa rede de interações, que é multilinear, não unilinear. Outro modelo que via a estrutura do enunciado de modo menos estático era a perspectiva funcional da sentença, da Escola de Praga, que, entre outras coisas, distinguia na oração informação nova (rema) e informação dada (tema), o que vai além da estrutura sintática sujeito-predicado.

Nos Estados Unidos havia mais modelos ainda. Eu vou falar brevemente apenas de dois. O primeiro é o dos constituintes imediatos, proposto pioneiramente por Bloomfield em 1933 e desenvolvido por Rulon S. Wells em 1947. É basicamente a representação arbórea adotada logo em seguida por Chomsky a partir de 1957 (ver figura 1 abaixo ), embora algumas versões desse modelo usem também representações do tipo "gramática da dependência", originada em Tesnière.

O segundo modelo é a tagmêmica, desenvolvida por Kenneth Pike partindo do conceito de tagmema, também proposto por Bloomfield. Uma grande inovação desse modelo é que vê a estrutura da língua como parte de algo maior. Enquanto o estruturalismo em geral se atém apenas à forma, a tagmêmica inclui também a função. Há uma organização hierárquica de níveis. Ela leva em consideração o nível do fonema, da palavra, passando pela frase, pela sentença, pelo parágrafo até chegar ao discurso. Mas Pike vai além do discurso, mostrando que a estrutura linguística era semelhante à de qualquer comportamento social, o que se pode ver em seu livro monumental "Language in relation to a unified theory of the structure of human behavior”, publicado em dois volumes em 1954 e 1955, respectivamente. O título já mostra claramente de que trata o livro.

Pike contribuiu grandemente também com os estudos fonéticos e fonológicos (fonêmicos), em seus livros "Phonetics" (1943) e "Phonemics" (1947). Partindo justamente da terminação das duas palavras, ele propôs também a distinção entre visão ética e êmica. A primeira é a de quem está de fora, que vê os fenômenos de modo "universal", não sua organização interna. A segunda, êmica, é a visão de dentro, de quem conhece o funcionamento e a estruturação do que é observado. Essa distinção foi adotada por muitas outras ciências, como a antropologia. Enfim, a proposta de Pike se aproxima bem mais da visão ecológica de mundo, uma vez que não isola a língua como um esqueleto inerte, separado de tudo de modo estanque. Pelo contrário, ele vê a língua como interação, tanto endoecológica quanto exoecológica. 
Há muitos outros modelos, nas duas tradições. Nos Estados Unidos, poderíamos mencionar ainda o distribucionalismo de Harris, a proposta de Charles Fries, a de Hockett e muitas outras. Na Europa, além da perspectiva funcional da sentença do funcionalismo de Praga, temos a glossemática de Hjelmslev, o funcionalismo de Martinet, a proposta semântica de Pottier e Greimas, entre outras. Lepschy (1972) apresenta um bom apanhado geral da linguística desse período. Mas eu gostaria de terminar esse tópico com a gramática gerativa e a gramática estratificacional.

Em 1957, Noam Chomsky propõe a gramática gerativo-transformacional, mais tarde apenas "gramática gerativa", que tem por centro a estrutura sintática. Ela a representa de forma bifurcante, arboreamente, mas sempre de maneira unidirecional, logo, estática. É o modelo que vê a língua como esqueleto de forma mais radical. Se é que há algum dinamismo na "língua" vista pelo estruturalismo e pela gramática gerativa (língua I), trata-se do dinamismo de gases no interior de um recipiente hermeticamente fechado: eles se movimentam constantemente, mas erraticamente, dentro dos limites do recipiente. Ultimamente, Chomsky tem tentado se aproximar de um modelo que veja a língua como algo dinâmico, como se pode ver em Hauser; Chomsky; Fitch (2002).

Na mesma época da proposta de Chomsky, surgiu a gramática estratificacional, proposta por Sydney M. Lamb. No início eles chegaram a polemizar. A proposta de Lamb é mais adequada à visão ecológica de mundo porque vê a estruturação da língua como indo da expressão ao conteúdo ou vice-versa, ou seja, a representação não é rigidamente unidirecional. O que é mais, sobretudo em suas versões ulteriores, ela passou a ver a língua como constituindo uma rede de interações (relational networks). Logo depois, Lamb começou a associar a estruturação da linguagem ao que se passa no cérebro, motivo pelo qual passou a chamar sua teoria de linguística neurocognitiva, que tem um interessante site na internet, chamado Langbrain. Enfim, não fosse sua herança estruturalista (Hjelmslev, Hockett), tratar-se-ia de um modelo que poderia ser adotado pela linguística ecossistêmica, sobretudo devido à terceira influência que teve, a de M. A. K. Halliday. A gramática estratificacional/ neurocognitiva representa uma transição entre a rigidez da visão estruturalista e a maleabilidade da visão ecológica.

Há uma ironia relativamente ao que são as duas tradições recém-vistas e o pai de cada uma delas. O ponto de partida da tradição europeia, Saussure, começou mostrando o esquema da interação comunicativa, com dois rostos virados um para o outro. A mensagem tem origem no cérebro do falante, vai para seus órgãos 
fonadores, que a associa a sons. Estes percorrem o espaço entre os dois, entram pelo ouvido do receptor e vão para o cérebro a fim de ser interpretados. A despeito de essa figura ter sido tachada de "circuito fechado", ela vai na direção certa, vendo na língua um tipo de interação. Algo parecido se dá com Bloomfield. No capítulo 2 do livro "Language" (1933), ele fala da interação entre Jack e Jill. O problema é que nenhuma das duas tradições continuou estudando a língua por essa perspectiva.

\section{Língua como organismo}

De certo modo, essa concepção de língua está antecipada no microcosmo renascentista, mas começou a se firmar para valer só no século XIX, na época dos comparatistas, como Rask, Bopp e Schleicher, portanto, bem antes da segunda fase da língua como esqueleto (seção anterior). No entanto, ela é superior às demais concepções de língua vistas acima, mesmo não dispondo de recursos para a representação gráfica dos fatos linguísticos. Ela é um avanço na concepção de língua porque organismo tem que ter, além do esqueleto, músculos e processos vitais. Infelizmente, porém, o organismo em tela é um organismo isolado e abstrato, que paira no ar. Não há interação entre ele e o mundo, como os falantes e o espaço em que se encontram, como prevê a visão ecológica de mundo e outras teorias modernas. Não há sequer o "metabolismo" existente em qualquer organismo vivo. Na linguística ecossistêmica, ao contrário, um tipo de metabolismo existe, e esse metabolismo está justamente no fato de o núcleo da língua ser a ecologia da interação comunicativa.

A despeito de Schleicher ter sido o introdutor do termo "morfologia" nos estudos linguísticos, essa tendência ainda não dispunha de recursos para representar o "organismo" da língua: nem do todo nem de parte dele. É verdade que Schleicher propôs um modelo de evolução cladogênica (por diversificação), às vezes anagênica (filética) da língua, aceito e adotado pelo próprio Darwin. De acordo com a primeira, a língua se ramifica em mais de uma, como aconteceu do latim para as línguas românicas. A segunda se dá quando há uma espécie de evolução linear da língua, como do grego antigo para o grego atual; não houve esgalhamento. Na cladogênese, a evolução das línguas se dá como do tronco para os galhos da árvore, donde o nome Stammbaumtheorie (teoria da árvore genealógica), proposta por Schleicher para designar seu modelo de evolução 
linguística. Trata-se de uma representação arbórea, como a adotada pela gramática gerativa mais tarde, mas com a "árvore” deitada. Seria isso um acaso, já que árvore caída é árvore morta?

Foi nessa época que surgiu a dialetologia e a geografia linguística, com suas representações geográficas em mapas, incluindo-se as isoglossas. Pelo menos no início dos estudos dialetológicos, a língua era vista como um organismo. Por exemplo, Charles Nodier (1780-1844) usou explicitamente a expressão langue organique. Nos desenvolvimentos ulteriores da geografia linguística, perdeu-se um pouco essa concepção, mas já se começou a ver a língua ligada ao contexto em que era usada, no caso, o espaço.

\section{Língua como espécie e como vírus}

Finalmente, entre as concepções de língua que precederam a que pretendo explorar, temos a de língua como espécie. Um de seus mais proeminentes defensores é Salikoko Mufwene, embora ela tenha sido antevista por Hermann Paul. Ele rejeita a ideia de língua como organismo que, em sua opinião, não é compatível com a realidade dos idioletos. Em vez de organismo, o autor equipara língua e espécie (lamarckiana), mais especificamente, espécie parasita, pois, como se sabe, a língua só existe no hospedeiro população. A língua comunitária seria um tipo de soma de todos os idioletos (Mufwene, 2001).

A língua como espécie parasita está bem próxima da visão da linguística ecossistêmica. De acordo com ela, o destino da língua está estreitamente dependente do destino do povo que a fala. De certa maneira, ela evita a reificação da língua, embora Mufwene continue com um modelo que parte dos idioletos para chegar à língua comunitária, ou seja, indo das partes para o todo. Isso lembra muito a língua como máquina das teorias antigas. Para a linguística ecossistêmica, isso existe apenas no caso do ecossistema mental da língua. Só como fenômeno mental a língua seria a somatória do que cada indivíduo tem armazenado em seu cérebro.

Pouco tempo depois, a concepção de Mufwene evoluiu de língua como espécie animal para língua como espécie viral. Os vírus estão intimamente associados ao comportamento social de seus hospedeiros. É esse comportamento que pode provocar e até disseminar as mudanças. Como nas espécies animais, a "interação da ecologia interna com a externa de uma língua lança luz não apenas sobre a causa 
das mudanças linguísticas, mas também sobre como essas mudanças se espalham" (MUFWENE, 2008, p. 23). Como nos vírus "os genótipos podem mudar durante sua vida, pode-se argumentar que a recombinação de vírus se dá mais de uma vez” (idem, p.18). O autor diz ainda:

...línguas ou dialetos são espécies de idioletos baseados na semelhança de família. Eles compartilham diversos traços com as espécies virais que são relevantes para o entendimento da evolução; por isso, o modelo da evolução biológica que os linguistas deveriam ter como inspiração parece estar na virologia ou na epidemiologia, não na biologia animal. As línguas são essencialmente como vírus pelo fato de serem espécies de parasitas cujas vidas dependem das atividades de seus hospedeiros, portanto, dos padrões de comportamento deles". (MUFWENE, 2008, p. 26).

Mufwene está interessado na ecologia da evolução linguística. Por isso a metáfora do vírus é mais apropriada, pois eles se propagam. Nesse sentido, sua proposta representa um avanço em relação à "língua como organismo". No entanto, continua aquém da concepção de língua como interação.

Curiosamente, a metáfora da língua como organismo, a ideia da associação da linguística com a biologia é comum nos meios gerativistas, como está discutido em Hauser; Chomsky; Fitch (2002), embora com a onipresente preocupação de separar a linguagem humana da "comunicação animal". A questão é tão problemática que no próprio meio gerativista a ideia foi refutada de ponta a ponta por Pinker; Jackendoff (2005). A ideia seguinte, de associar língua a vírus também tem sido discutida nesse meio (PIATELLI-PALMARINI; URIAGEREKA, 2004), usando conceitos da biolinguística, só que de uma biolinguística hipotético-dedutiva, como sói acontecer com toda a tradição em que a teoria se enquadra, estudando um organismo isolado do meio, como se faz desde a Antiguidade.

\section{Língua como interação}

Como se pode ver nos pequenos grupos étnicos ainda sobreviventes, as primeiras concepções de língua (a Ursprache, como se diz em alemão), aquelas que surgiram antes dos primeiros "filólogos" normativistas, eram intuitivas. Língua era o modo de as pessoas interagirem entre si verbalmente. Até mesmo em latim não se dizia "falar latim", mas latine loqui, ou seja, falar como os latinos. 
Essa concepção desapareceu com as primeiras reflexões sobre a língua, que, como vimos, eram de caráter normativo, logo, pressupunham um sistema ideal, que devia ser imitado. Vale dizer, excetuando as concepções laicas dos povos primevos e algumas manifestações isoladas de intelectuais, a concepção normativa de língua perpassa por toda a história, da Antiguidade aos nossos dias. É verdade que em Heráclito (cerca de 500 a.C) essa concepção estava implícita, mas ela desapareceu nos pensadores que o sucederam, só reaparecendo em autores isolados e em alguns filósofos a partir do século XIX, como Hegel (1770-1839) e Humboldt (17671835). Este último sempre enfatizou que a língua não é um érgon (algo feito), mas enérgeia (atividade). No século XVI, houve o já mencionado caso de Juan Luis Vives.

Vimos, na seção 2, que língua são as interações (verbais) que se dão no ecossistema linguístico, assim como o que interessa no ecossistema biológico não é a população de organismos vivos nem seu território em si, mas as interações que se dão entre eles. Por isso, o núcleo da língua se encontra no diálogo. Mas, a interação comunicativa segue alguns padrões, e padrão é regra. Só que, no caso, se trata de regra-regularidade, oriunda do hábito, dos padrões que vão se formando na interação comunicativa, ou seja, das regras interacionais, não de regraregulamento, normativo-impositiva, ou seja, as regras sistêmicas (gramática) (Couto, 2015: 37-62). Aliás, na linguística ecossistêmica as regras sistêmicas são parte das regras interacionais, logo, subordinadas a elas. Na tradição linguística, no entanto, o uso (parole, desempenho) é uma realização do sistema (langue, competência), é dependente do sistema, posição que, como já vimos, põe o carro na frente dos bois.

Vejamos o caso da teoria da otimalidade (optimality theory), em que se fala em regras violáveis (violable constraints), e que a violabilidade deve ser mínima. O problema é que essa teoria fica inteiramente no domínio do sistema fechado, de modo que seus seguidores só falam em termos de regras sistêmicas. Outro problema é que ela não explicita quem as viola nem em que circunstâncias são violáveis. Na linguística ecossistêmica, em princípio todas as regras podem ser violadas, sobretudo as regras sistêmicas. Isso porque o objetivo dos interlocutores em diálogo não é produzir frases gramaticais, mas fazerem-se entender. Se o entendimento se dá, não consideram nada anormal. A diferença em relação à teoria da otimalidade consiste no fato de que a linguística ecossistêmica diz por que determinada regra pôde ser violada. Isso acontece porque a intenção do 
falante é recuperada na própria dinâmica da ecologia da interação comunicativa (informações compartilhadas, contexto etc.). De um modo geral, podemos dizer que praticamente toda regra sistêmica pode ser violada, como na ordenação de locuções na oração, de orações no período, de períodos no parágrafo e de parágrafos no texto, fato corriqueiro nas falas reais. Talvez só não seja possível violação das regras morfológicas e fonológicas. Com efeito, é bem provável que em nenhuma variedade do português os morfemas que entram na palavra "des.em.barg.a.dor' ocorram em outra ordem que não essa. Sequências como *“em.des.barg.dor.a”, *“barg.dor.a.em. des" e outras são inaceitáveis pelo falante, de qualquer dialeto do português. $\mathrm{Na}$ estrutura silábica também. Jamais ocorreriam formas como "rap", "arp" ou "pra” no lugar da forma canônica "par", como em "par.tir". No nível sintático, no entanto, basta observarmos conversas do dia a dia, sobretudo na zona rural, para vermos que a maior parte das frases proferidas infringem as regras sistêmicas (gramática).

A concepção que sigo aqui é a de língua como interação, que pode estudar inclusive questões de gramática. No entanto, trata-se de representações não em forma de árvores unidirecionais, estáticas, mas de redes orgânicas. Com isso, passo ao objetivo principal deste artigo.

\section{A língua como rede de interações orgânicas}

Quase se poderia dizer que se trata de língua como organismo, mas, como esse termo vem eivado de conotações schleicherianas, é melhor nos atermos a língua como ecossistema. Vale dizer, em seu arcabouço até que existem organismos (os usuários), mas a língua em si não é um organismo, embora apresente organização interna e externa. Ela tem uma ecologia interna (endoecologia), mas faz parte da ecologia externa (exoecologia). A primeira troca matéria, energia e informação com a segunda. Aí está a diferença fundamental entre a linguística tradicional e a linguística ecossistêmica. Esta prefere lidar com o termo organização, constituída de uma rede de interações orgânicas (RIO). No interior dessas redes, podemos delimitar determinado domínio como o ecossistema que vamos estudar. Em seu interior, há subecossistemas, sub-subecossistemas e assim por diante.

A estrutura, no sentido da linguística estrutural e, sobretudo, da gramática gerativa, talvez seja o subecossistema mínimo a que se pode chegar em determinado domínio. Nesse ponto, as leis da mecânica de Newton podem e devem ser aplicadas. É aí que elas têm validade. É aí que pode e deve entrar a gramática gerativa. 
Um conceito surgido na filosofia que é muito parecido com o da RIO é o do rizoma, tomado da botânica por Gilles Deleuze e Felix Guattari, na Introdução ao volume I do livro “Mil platôs”. Segundo os autores, o rizoma “é aberto, é conectável em todas as suas dimensões". Com efeito, "o pensamento não é arborescente e o cérebro não é uma matéria enraizada nem ramificada”, ele é uma multiplicidade. Ainda segundo os autores, "uma das características mais importantes do rizoma talvez seja a de ter sempre múltiplas entradas". "Diferentemente das árvores ou de suas raízes, o rizoma conecta um ponto qualquer com outro ponto qualquer e cada um de seus traços não remete necessariamente a traços de mesma natureza", o que, na linguística significa que se pode conectar um ponto do nível morfológico com um do semântico, um sintático com um fonológico e assim por diante. É muito diferente da árvore ou da raiz que fixam um ponto, uma ordem”. Portanto, ele é "oposto a uma estrutura, que se define por um conjunto de pontos e posições". A árvore sintagmática de Chomsky começa por um ponto e procede unidirecionalmente por dicotomia. Enfim, "um rizoma não pode ser justificado por nenhum modelo estrutural ou gerativo". No entanto, ele "é feito de platôs", reportando-se a Gregory Bateson. No caso, o "platô" seria o segmento delimitado pelo observador, num procedimento semelhante ao do ecólogo delimitando o ecossistema que vai estudar. Aí é possível detectarem-se árvores binárias (DELEUZE; GUATTARI, 2000).

Como disse Madeira (1994), a metáfora "usada por Gilles Deleuze e Félix Guattari [...] significa, de forma mais imediata, um corte com certa tradição do pensamento moderno, dos estruturalistas a Freud, ao mesmo tempo em que repropõe a ideia heideggeriana de pensamento sem fundação" (MADEIRA, 1994, p. 28). Essa proposta está em perfeita sintonia com a do "paradigma ecológico" comentado na seção 9 .

Vimos na seção anterior que o núcleo da língua é a interação comunicativa, uma vez que ela é o modo tradicional de os membros da comunidade interagirem verbalmente. Aqui se estuda o produto da ecologia da interação comunicativa, constituído de "enunciados", "frases", "orações", "sentenças", "períodos” etc. A linguística tradicional isola essas entidades e estuda sua estruturação interna, vendo seus "constituintes" estruturados linearmente. A linguística ecossistêmica também lhes reconhece uma estruturação, mas não de estruturas tomadas isoladamente. Há um encadeamento reticular, não linear, de modo que cada "ponto" da estrutura se relaciona com diversos outros "pontos" de diversas outras estruturas possíveis. 


\subsection{A representação estrutural-gerativa}

Antes de apresentar os primeiros resultados da organização endoecológica da língua na forma de redes de interações orgânicas, vejamos algumas das principais representações que a precederam. Deixando de lado a representação estemática de Tesnière, a dos constituintes imediatos de Wells e outras, começo pela representação arbórea da gramática gerativa, a exemplo da oração de (1).

FIGURA 1: (1) O caçador cruel matou o leão velho

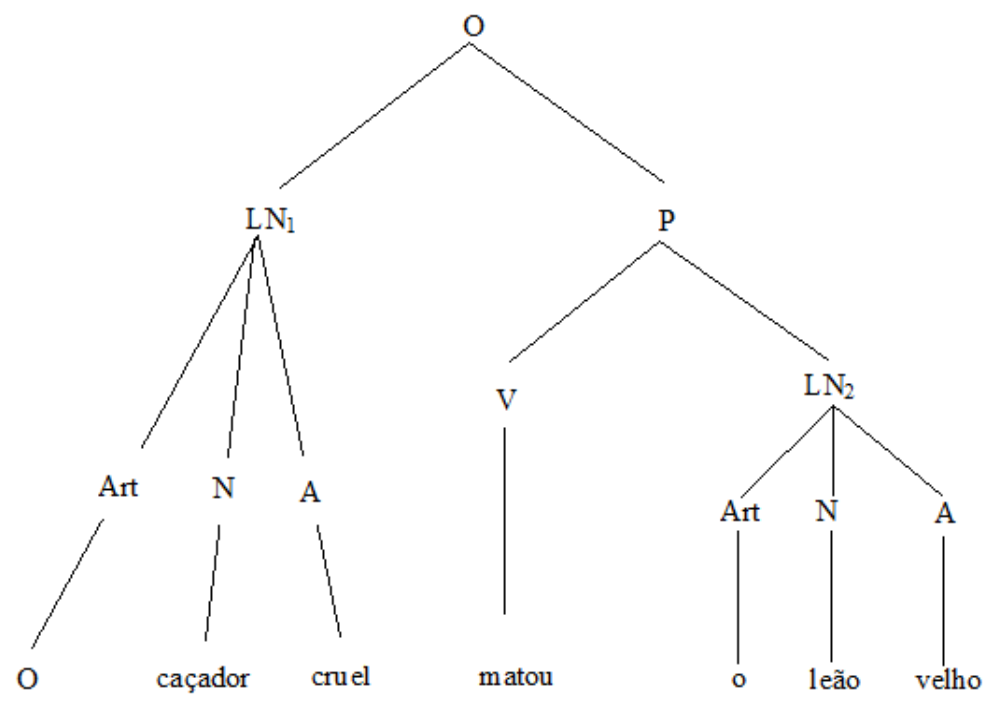

Trata-se de uma representação rigidamente unilinear e unidirecional, mais até do que a estruturação dos ossos que compõem o esqueleto de um animal. Não se trata de representação errada nem sem validade. Pelo contrário, dentro do limitadíssimo domínio de uma oração isolada de tudo, é talvez a melhor representação possível. No entanto, na cabeça dos falantes não é assim que a endoecologia da língua está organizada.

Além de unilinear e unidirecional, ela é também binária, bifurcante. É o modelo que representa a língua como esqueleto por excelência. Para ele, língua é algo engessado, congelado, como querem os gramáticos normativos que a língua seja, 
isto é, não dinâmica, constantemente adaptando-se às novas circunstâncias em que seus usuários se encontram. Na seção 8.3, veremos que a representação reticularrizomática contém esse aspecto (no sentido de Ortega y Gassett) da língua em seu interior. Vale dizer, a visão gerativa também é válida, mas apenas para um átomo no interior da rede de interações orgânicas que constituem a língua.

\subsection{A representação estratificacional-neurocognitiva}

Vimos que a gramática estratificacional/neurocognitiva, que surgiu na mesma época que a gramática gerativa, vai um pouco além dela, subvertendo sua unilinearidade e unidirecionalidade. O que é mais, ela pode representar a estrutura da oração exatamente como o faz a gramática gerativa, o que se pode ver na figura 1.

\section{FIGURA 2}

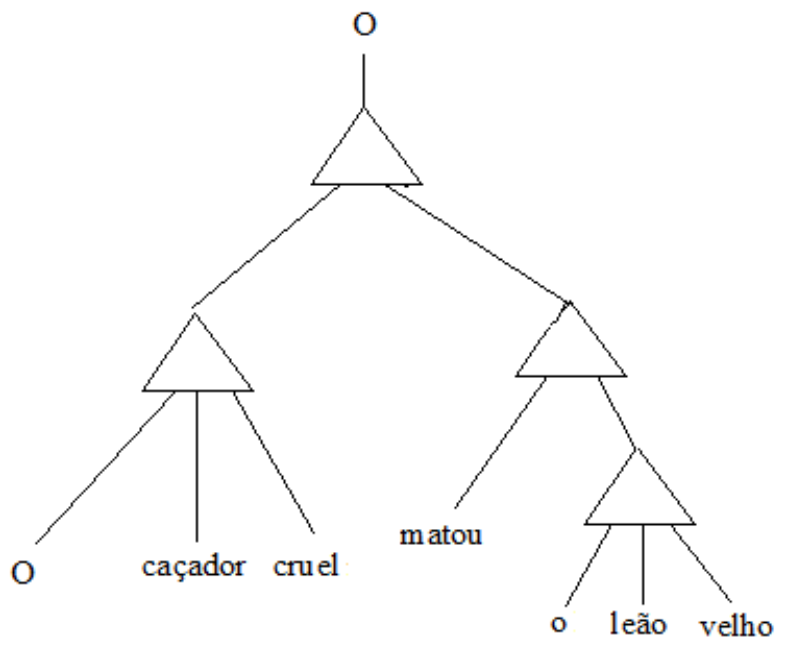

No entanto, devido a sua maior maleabilidade e ao fato de ver os fenômenos linguísticos como "redes de relações" (relational networks, como dizem seus praticantes), vai um muito além da unilinearidade e unidirecionalidade da representação gerativa. Vejamos o gráfico da figura 2, que representa a mesma oração que o da figura 2, mas também algo adicional. 


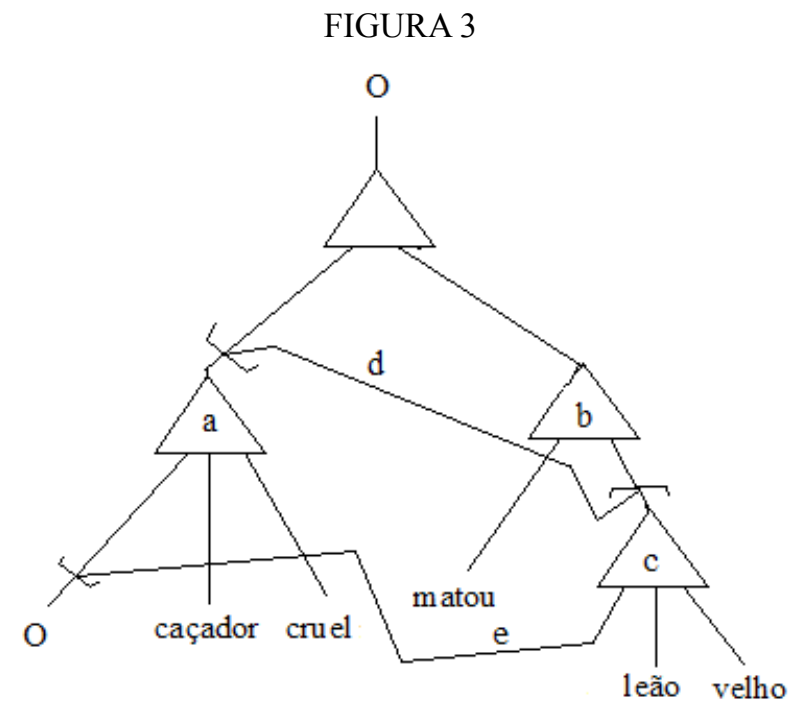

Se lermos a figura 2 na sequência dos triângulos "a", "b" e "c", temos a mesma representação da árvore gerativa, ou seja, "O caçador cruel matou o leão velho". No entanto, ela não se limita a isso. Lendo-a no sentido "a", "b" e "d", temos a representação de "O caçador cruel se matou", ou seja, a reflexividade. Finalmente, ela pode ser lida no sentido "a", "b", "c", com o primeiro constituinte de "c" sendo remetido ao primeiro de "a'. Isso mostra que o "o" de "o leão velho" é o mesmo de "o caçador cruel". Há inúmeras outras possibilidades, inclusive de associação dessa oração com outras.

Para um exemplo semântico, vejamos o que Sydney Lamb diz do conceito de gato, (cat). Melhor dizendo, como ele está inscrito no cérebro/mente dos falantes, uma amostra das conexões que ele mantém. Vê-se que o que ele diz poderia perfeitamente ser usado em uma exposição linguístico-ecossistêmica, com pequenas adaptações.

Partindo do conceito ${ }^{C}$ cat, por exemplo, temos conexões visuais com o que se assemelha a um gato, conexões auditivas para o 'miau' e outros sons emitidos pelo gato, conexões táteis para o que sentimos no contato com o gato. Há também conexões com outros conceitos que representam informações sobre gatos no sistema de informação da pessoa em cujo sistema essas conexões foram formadas. Assim, o conhecimento de uma pessoa sobre gatos está representado no sistema de informação por uma pequena rede, que contém centenas, milhares de nós, incluindo uma sub-rede para os 
traços visuais, uma rede auditiva para o 'miau' e assim por diante, todos esses nós 'mantidos juntos' por um nó central coordenador, ao qual podemos dar o rótulo de ${ }^{C}$ cat (LAMB, 2000, p.177).

Isso é uma pequena amostra do que pode fazer a linguística neurocognitiva. Sua representação em redes de relações (relational networks) já apresenta uma certa maleabilidade que se aproxima bastante da representação reticular. Ela só não pode ser apropriada na íntegra pela linguística ecossistêmica porque se filia à tradição que vê a língua como um instrumento: para comunicação, no estruturalismo; para expressão do pensamento, no gerativismo e na linguística neurocognitiva. Ora, instrumento é uma coisa que uso para fazer outra. A linguística ecossistêmica vê a língua não como instrumento para comunicação ou expressão do pensamento, mas como a própria comunicação e expressão do pensamento. Como as demais teorias estruturalistas, a linguística neurocognitiva também parte do sistema para o uso, num procedimento que já foi chamado de por o carro na frente dos bois.

Para mais detalhes sobre essa teoria, com muitos exemplos de análises, podese ver Lamb (1966, 1999, 2000), Makkai (1993) e Couto (1982). O primeiro livro de Lamb é uma das primeiras exposições dos princípios da teoria. O segundo e o terceiro já associam a representação dos fenômenos linguísticos com o modo pelo qual eles estão representados no cérebro, donde o nome linguística neurocognitiva. Quanto ao de Makkai, além de uma associação desta vertente da linguística com a ecolinguística, contém diversas representações de fenômenos fonológicos (como os traços distintivos se "estruturam"/organizam), morfológicos, sintáticos e semânticos. O livro de Couto, por fim, é uma tentativa de aplicar a teoria ao português.

\subsection{A representação ecossistêmica: reticular-rizomática}

Passemos à representação dos fenômenos endoecológicos da língua em forma reticular, como rede de interações orgânicas (RIO), rizomáticas. Partindo de uma oração como "José ama Maria", proferida em um ato de interação comunicativa, a LE mostra que, na cabeça dos usuários, nenhum dos termos está isolado dos demais, todos fazem parte de paradigmas (no sentido saussuriano), de modo que uma forma leva a outra, que leva a outra, que leva a outra e assim por diante, como está sugerido na figura 3 . 


\section{FIGURA 4}

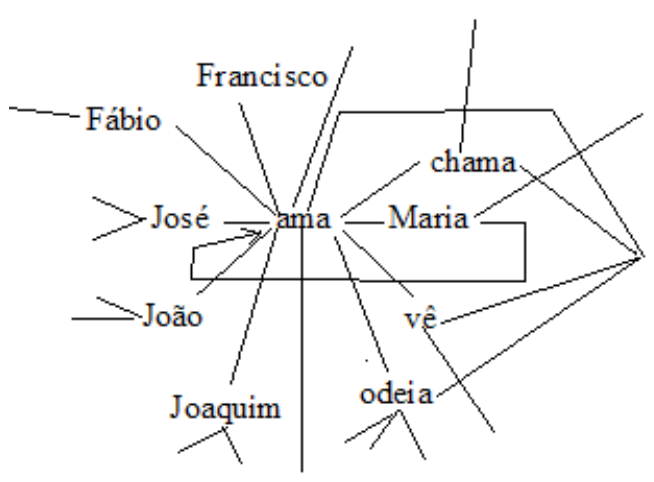

A representação não é unilinear nem unidirecional, mas multidirecional. A rede orgânica não é plana nem unidimensional, mas pluridimensional. Os verbos não se associam apenas pela forma que se vê no gráfico, mas irradiam para todos os lados. Todos estão ligados a "terceira pessoa do singular", a "presente", a paradigmas de primeira (ama, chama, odeia) e segunda conjugação (vê) etc. A reflexividade está indicada pela laçada (loop) que liga o sujeito a si mesmo, como na figura 2 e assim por diante. Como se pode ver nas linhas que partem para fora do gráfico, há inúmeras outras interconexões que não foram representadas. No entanto, no conhecimento dos falantes elas existem, implícita ou explicitamente, patentes ou latentes.

Aparentemente, tratar-se-ia de uma representação não muito diferente da neurocognitiva. Só não é idêntica porque a RIO tem por base epistemológica a nova visão de mundo, ecológica, ao passo que a neurocognitiva ainda está muito presa aos postulados do estruturalismo. A linguística neurocognitiva vê a língua apenas como fenômeno neuropsíquico, o que ela realmente também é, ou seja, ela a vê apenas como expressão do pensamento. Ignora a faceta principal da língua, que é a interacional-comunicativa, atendo-se só à interacional-expressiva. A RIO, além conter tudo isso, está em sintonia com o novo paradigma científico de que fala Fritjof Capra mais abaixo, bem como com a proposta dos rizomas dos filósofos franceses Félix Guattari e Gilles Deleuze. A língua passa a ser vista como interação comunicativo-expressiva: justamente as duas interações básicas do ecossistema.

No caso da morfologia, é mais fácil mostrar a multilateralidade das interações, 
como se pode vislumbrar no segmento da rede de interações morfológicas do português visto na figura 4 .

\section{FIGURA 5}

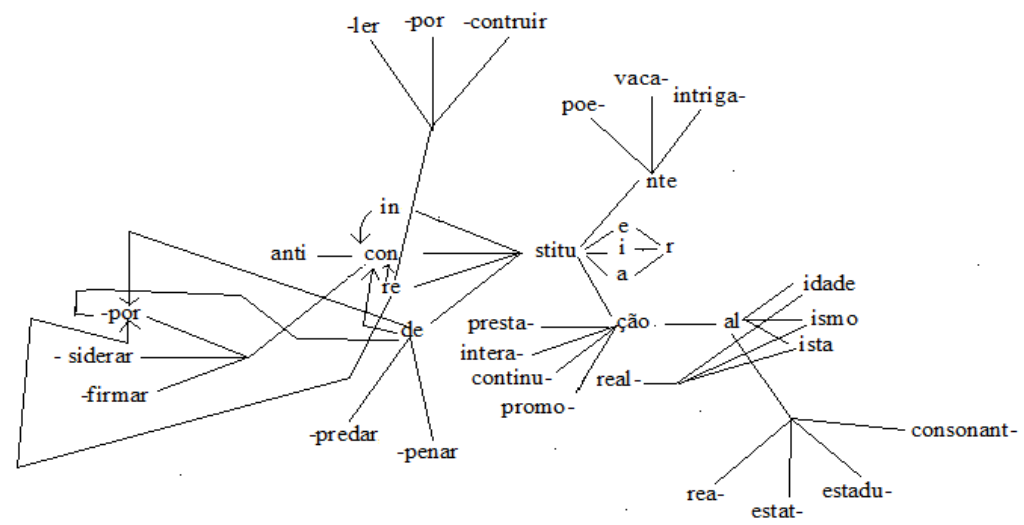

Parece complicado? A realidade é complicada. O mundo é uma realidade complicada. Não há como representar realidades complexas pela maneira simples que gostaríamos. Tanto que atualmente a língua vem sendo considerada um "sistema complexo" por diversos autores, como se pode ver em Oliveira (2014, 2015). A língua é um fenômeno complicado. A complicação da figura 4 representa uma certa iconicidade que deve haver entre modelo teórico e a realidade a que se refere, com as restrições apresentadas por Alfred Korzybski, que disse que o mapa não é o território.

Partindo de um segmento de rede como "anti.con.stitu.cion.al.ismo", notase que cada ponto (nó) está ligado a inúmeros outros na mente dos falantes. Alguns segmentos da rede, como o que acaba de ser mencionado, são usualmente empregados pelos membros da comunidade. Outros, existem como potencialidades, que podem ou não ser acionadas. De qualquer forma, essas potencialidades fazem parte do conhecimento linguístico dos falantes. Mas, não se trata da competência da gramática gerativa, porque o conhecimento em questão contém as regras interacionais, e são estas que dizem aos falantes quais formas estão em uso e quais não estão. É assim que a realidade endoecológica da língua está organizada no cérebro, e é no cérebro que tudo se estrutura, ou melhor, se organiza.

O conhecimento dos falante inclui não apenas "anti.con.stitu.cion.al.ismo", "anti.con.stitu.cion.al.ista" e "anti.con.stitu.cion.al.idade", mas também *“anti-in. 
con.stitu.cion.al.idade", *“anti.rre.sticionalidade”, *“anti.des.stitu.cion.ali.dade”, * "anti.rre.stitu.cion.al.ismo", enfim, todas as combinações previstas pelas regras sistêmicas (gramática). Para a linguística ecossistêmica, a endoecologia da língua é composta não apenas de formas "ativadas" (que estão em uso), mas também das "inativadas" (que ainda não são usadas, mas poderiam ser), das "desativadas" (arcaísmos) e das "reativadas" (palavras que caíram em desuso por algum tempo e voltaram a ser usadas posteriormente).

Vale dizer, a língua numa visão holística é muito mais do que o que nos mostram as gramáticas normativas e a gramática gerativa. Tanto que a qualquer momento se pode ativar uma forma prevista mas ainda não usada, como fez o ex-ministro Magri com * “imexível”, uns tempos atrás. Toda a dificuldade da gramática gerativa inicial de explicar a diferença entre gramaticalidade e aceitabilidade é uma dificuldade criada pela própria teoria.

Outros domínios da língua podem ser representados como ecossistema linguístico. Um deles é o "ecossistema articulatório". Nesse caso, o som (S) é resultado imediato dos movimentos dos articuladores móveis (M) relativamente aos articuladores fixos (F). Isso significa que $\mathrm{S}$ equivale ao lado "língua" (L) do tripé linguístico-ecossistêmico. M corresponde ao lado "população" (P), ou seja, o lado dinâmico, ativo. F, por fim, representa ao lado "território" (T), isto é, o locus em que o som é produzido, o ponto de apoio para o órgão móvel articular o som. Isso está mostrado na figura 5.

FIGURA 6

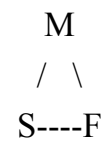

Ecossistema Articulatório

Coseriu (1956: 32) menciona a "ecología de la articulación”, mas acha que ela é um problema "que debe plantear y resolver la biología". Independentemente dessa opinião, o fato é que o modelo ecossistêmico inclui até o lado físico da interação linguístico-vocal. Algo semelhante vale para a face semântica, como já sugeriam os campos semânticos de Jost Trier e as relações paradigmáticas de Saussure, além da ecologia das relações espaciais das preposições (COUTO, 2010). 
A representação RIO-rizomática é holística. Mas, no interior do rizoma é possível delimitar estruturas do tipo gerativo. Assim, na representação sintática da figura 3 é possível focalizarmos o "platô" (plano) “José ama Maria” e analisá-lo em forma arborescente, unidirecional, binária. O mesmo pode ser feito, por exemplo, com a linha "anti.con.stitu.cion.al.ismo" da figura 4, para a morfologia. No entanto, é importante o analista ter em mente que ao fazer isso está aproximando o foco apenas provisoriamente (GARNER, 2004, p. 202-204) para estudar detalhes finos. Assim que terminar essa análise, deve recuar para ter a visão abrangente da rede ou do rizoma. Assim, o objeto não fica engessado em um modelo que só tem esqueleto. Ele é visto como um organismo dinâmico, um ecossistema endo- e exoecológico, ou seja, que além das interações internas mantém também interações com o que está em seu entorno, imediata ou mediatamente.

Focalizar determinado segmento da rede é como delimitar um ecossistema na ecologia. Melhor, é como fixar-se em determinado fenômeno do ecossistema, por exemplo, apenas na população ou parte dela ou, por outro lado, apenas no habitat ou território ou parte dele. Ao analisar qualquer parte desses fenômenos, o ecólogo não perde nunca de vista o contexto ecossistêmico em que ela se insere. Normalmente, porém, após delimitar o ecossistema, ele analisa seu interior com a maior precisão científica possível.

$\mathrm{Na}$ atualidade, há mais de uma vintena de teorias linguísticas interacionais (COUTO, 2014a), embora nenhuma delas tenha recursos para representar “estruturas". Nem o funcionalismo, de que há várias correntes. Isso porque a língua não é um fenômeno apenas mental, como quer a gramática gerativa, nem apenas social, como nos dá a entender a sociolinguística, nem, muito menos, um fenômeno de natureza apenas física e química, como diz Chomsky e algumas correntes filosóficas. Na verdade, ela apresenta as três facetas, como vimos na seção 2. Ele é um fenômeno biopsicossocial.

Enfim, todos os modelos estruturalistas, gerativistas veem a língua como uma máquina de produzir frases, uma vez que vai do sistema de regras para elas. Tanto que no modelo de Saussure, os atos de fala são "realizações" do sistema; até mesmo em Benveniste, que tentou ultrapassar essa visão mediante a teoria da enunciação. Tanto que ele deixa claro que a fala se dá mediante o por em prática da língua (langue). O mesmo se pode dizer da gramática gerativa, para a qual a sentença é o desempenho de uma competência linguística. 


\section{O paradigma ecológico comparado ao de base cartesiano-newtoniana}

Fritjof Capra fala de um novo paradigma para o estudo das ciências em geral, sobretudo a física, que ele chama de paradigma ecológico. Segundo o autor, "enquanto que na física clássica, as propriedades e o comportamento das partes determinam as propriedades e o comportamento do todo, na física quântica a situação é a inversa: o todo é que determina o comportamento das partes" (CAPRA, 2008, p. 231). Aplicando isso à linguagem, o todo é a interação comunicativa, localizada na respectiva ecologia da interação comunicativa.

Ainda segundo Capra, há "uma mudança do pensamento em termos de estrutura para o pensamento em termos de processo" (idem, p. 244), confirmando mais uma vez a prioridade da interação comunicativa sobre o sistema. Nesse caso, "o universo material é visto como uma teia dinâmica de eventos [...] e a consistência global de suas inter-relações determina a estrutura de toda a teia" (idem, p. 247). Em Capra (1998, p.11-13), o autor apresenta uma lista de cinco características dos dois modelos, discutindo-as e salientando a diferença entre eles: a) mudança da parte para o todo; b) mudança de estrutura para processo; c) mudança de ciência objetiva para "ciência epistêmica"; d) mudança de construção para rede como metáfora do conhecimento; e) mudança de descrições verdadeiras para descrições aproximadas.

Uma ironia difícil de entender é que o modelo teórico que vem sendo praticado desde o final da década de cinquenta do século passado está no nível da mecânica de Newton (1642-1727) e da filosofia de Descartes (1596-1650), não no da ciência moderna, como a teoria da relatividade, a mecânica quântica, a ecologia, a teoria da complexidade (MORIN, 2002, 2007), de que há um apanhado em Oliveira (2014), e outras. Essas teorias vêm mostrando desde a década de vinte do século passado que a realidade não é como uma máquina, que pode ser desmontada em suas peças e depois montada de novo. Sequer é ela um organismo isolado, constituído pela soma de partes e que pode ser esquartejado e depois recomposto. Nós não estamos dentro de uma bola, dentro da qual as leis da mecânica de Newton são perfeitamente válidas. O mundo é uma imensa rede de interações, em que tudo está relacionado a tudo, sem limites conhecidos. Não se compreende por que Chomsky se atém ao modelo newtoniano, mesmo estando bem consciente dos achados da física moderna. 
A visão ecológica de mundo restabeleceu a visão de realidade como ela é efetivamente. É nesse contexto que se insere a linguística ecossistêmica. Essa nova visão não exclui o sistema. Podemos, e devemos, realmente delimitar um pequeno domínio do objeto de estudo, como faz a ecologia com o ecossistema, a fim de estudá-lo nos mínimos pormenores, numa visão microscópica. Após delimitado, determinado segmento da rede de interações pode ser encarado, provisória e operatoriamente, como uma estrutura, que pode ser estudada mediante regras mecânicas como as do sistema cartesiano-newtoniano. Nesse nível, é possível estudar na língua orações clivadas, encaixamentos, orações relativas (na sintaxe) e peso da penúltima sílaba como fator determinante da posição do acento em português (na fonologia) e assim por diante.

Em vez de "estruturas linguísticas", a linguística ecossistêmica parte de "redes linguísticas". Assim, teríamos redes lexicais, ou léxico-semânticas, redes sintáticas, redes morfológicas, redes fonético-fonológicas etc. Resta investigar se há "ecologia da percepção", "ecologia das ondas/vibrações sonoras", "ecologia da percepção" e "ecologia da interpretação pelo cérebro". Interação fonatória, correspondente à ecologia da interação comunicativa, existe. Basta dar uma olhada na primeira figura do capítulo III do "Curso de linguística geral”, de Saussure.

Por fim, gostaria de mostrar que as teorias estruturalistas e gerativistas geralmente apenas descrevem fenômenos. Elas conseguem explicar apenas aqueles cuja explicação é possível por leis que estão no nível da mecânica de Newton. $\mathrm{Na}$ fonologia, mostra que se a última sílaba da palavra for pesada o acento deve recair sobre ela, situação não marcada (cortar, cartão, Niterói). Se não cair nela, temos situações marcadas, que devem ser decoradas (fácil, mártir, ímã, sótão). Explica também a queda da vogal postônica dos proparoxítonos, que já ocorria no latim vulgar (córrego > corgo, abóbora $>$ abobra, chácara $>$ chacra). Essas teorias demonstram que isso ocorre quando a vogal da penúltima sílaba é leve. Porém, elas são incapazes de explicar diversos outros fenômenos, ficando apenas no nível descritivo, em que são insubstituíveis.

Vejamos dois exemplos. Primeiro, temos algumas configurações silábicovocabulares que não admitem a proparoxitonidade, como *“bárbicha”, *“cánalha”, *“cáminho", *“gândaia”, *“Marácanã, *“cáteter, *“cárretel, *“arrématam, * “sóterra". Pelo que sabemos até o presente, isso não se explica por critérios meramente sincrônico-estruturais. Como esse assunto foi minuciosamente examinado em Couto (2008), vou comentar apenas oúltimo exemplo, aparentemente 
o mais complicado. A sequência de letras "rr" em uma palavra como "terra" era interpretada na fonologia do latim efetivamente como duas consoantes, ou melhor, como uma geminada que, ao fim e ao cabo, equivalia a duas consoantes, portanto, a divisão silábica era como em "ter.ra". Isso significa que a penúltima sílaba era pesada, por ter coda. Ora, se a penúltima sílaba era pesada, o acento não podia cair na sílaba anterior, pois isso produziria uma forma pró-proparoxítona, inadmissível no latim e no português. Pois bem, como a linguística ecossistêmica leva a dimensão temporal em conta, explica a não ocorrência de * "só.te.rra" pelo fato de os falantes terem memória inconsciente dessa origem da estrutura, mesmo que as geminadas não ocorram mais. Essa forma ainda seria sentida como * "só.ter.ra". Do mesmo modo, determinados genes (como "olhos azuis") podem não ocorrer no filho, mas reaparecer no neto ou no bisneto, o que significa que permaneceram latentes por algum tempo.

Em segundo lugar, temos a questão da concordância sujeito-predicado e núcleoadjuntos no interior da locução nominal. A sociolinguística variacionista tem feito inúmeras pesquisas mostrando o mecanismo sincrônico de sua ocorrência/ não ocorrência. No entanto, não explicou por que construções como *“os menino pequeno- " $\mathrm{e}$ *"as menina canta-" ocorrem. Dizer que o fenômeno ocorre $\mathrm{x} \% \mathrm{em}$ uma situação e y\% em outra não é explicar, mas mostrar. Em Couto (2014b), argumentei que a flexão de número em situações como essas é desnecessária para a comunicação. Tanto que no português rural elas praticamente inexistem. Ora, tudo que é dispensável é dispensado em situações informais e na ausência da pressão normativa do português estatal (preferível a "padrão"). Mais precisamente, essas flexões não existem no português rural. As pessoas interagem para se entenderem, não para produzir frases gramaticais, à la gramática gerativa.

\section{Observações finais}

Como vimos, não há uma única maneira de representar os fenômenos da endoecologia da língua, o que a tradição tem chamado de "estrutura", "gramática", sendo esta última dividida em "sintaxe", "morfologia", "fonologia" e, talvez, a "semântica", para deixar o "léxico" de lado. A tradição, sobretudo a gramática gerativa, tem superenfatizado o que diferencia a "linguagem" dos "meios de comunicação" dos animais. A ecolinguística procura ver o que têm em comum. Por esse motivo parte da ecologia da interação comunicativa para chegar ao 
sistema (langue), não de um sistema que permite "realizar" a fala (parole). $\mathrm{O}$ que fiz aqui foi apenas propor algumas possibilidades de análise, que podem ser válidas ou não. Se válidas, espero que outros pesquisadores deem continuidade às investigações.

A linguística ecossistêmica é um arcabouço geral para se praticar linguística. Ela pode englobar as demais teorias linguísticas, no sentido de se valer delas quando necessário, mas, de posse dos resultados parciais e parcelares obtidos com elas, retornar ao posto abrangente e avaliá-los. É o procedimento metodológico recomendado por Garner (2004), com seu “método da focalização". Uma grande vantagem da linguística ecossistêmica é que está no contexto da moderna visão de mundo, perfilhada pelas ciências exatas, pela ecologia, pela teoria dos sistemas complexos e pela teoria do caos. As teorias estruturalistas estão no nível da filosofia cartesiana e da mecânica clássica.

Por fim, gostaria de apontar para um possível uso das representações reticularrizomático-ecossistêmicas no ensino de língua. Elas mostrariam ao aluno que as palavras não estão isoladas. Bastaria ele se conscientizar de como os fenômenos estão organizados na mente, mediante representações multidirecionais. Até o leigo faz associação de ideias, em todas as direções.

\title{
Grammatical studies according to ecosystemic linguistics
}

\begin{abstract}
The main objective of this article is to present arguments in favor of a rhyzomatic-recitular representation of what tradition has called linguistic structure, using the version of ecolinguistics known as ecosystemic linguistics. It begins with a historical overview of conceptions of language along history, showing that the first lay conceptions were in line with modern science, but the first reflections on language were normative, and presupposed a static system. The first attempts at representing linguistic phenomena appeared in the realm of semantics and phonetics-phonology. In syntax, the first representations may have been Lucien Tesnière's stemmata and the immediate constituents of the American structuralism.
\end{abstract}


The conception of language as a skeleton by the first "philologists" continued and was ameliorated by structuralism and generative grammar - both lie at the level of Newton's mechanics and Descartes' philosophy. It was with stratificational grammar - now neurocognitive linguistics - that representations began to take into consideration the fact that language is a dynamic, non-linear and non-unidirectional. The view of language as organism and as virus, respectively, was followed by the ecosystemic view, according to which it is basically interaction, and its representations should be as reticulum and rhizome, multilateral and multidirectional. Theses representations are more wide-ranging and contain the others.

Keyswords: Structure. Network; Rhyzome. Ecolingustics. Ecosystemic linguistics.

\section{Referências}

AMMIROVA, T. A.; Ol'chovikov, B. A.; Roždestvenskij, J. V. Abriss der Geschichte der Linguistik. Leipzig: VEB Bibliographisches Institut, 1980.

CAPRA, Fritjof. Pertencendo ao universo: Explorações nas fronteiras da ciência e da espiritualidade. São Paulo: Cultrix/Amana, 1968, 10ed.

COSERIU, Eugenio. La geografia linguística. Montevidéu: Fac. Hmanidades/ Universidad de la República.

COSERIU, Eugenio. Lições de linguística geral. Rio de Janeiro: Ao Livro Técnico, 1980.

COUTO, Hildo Honório do. Linguística e semiótica relacional. Brasília: Thesaurus, 1982.

COUTO, Hildo Honório do. Ecolinguística: Estudo das relações entre língua e meio ambiente. Brasília: Thesaurus, 2007.

COUTO, Hildo Honório do. Algumas restrições aos proparoxítonos em português. In: RONCARATI, Cláudia; ABRAÇADO, Jussara (Orgs.). 2008. Português brasileiro: Contato linguístico, heterogeneidade e história. Niterói: EdUFF, p. 118-136.

COUTO, Hildo Honório do. Ecologia das preposições espaciais portuguesas. Lusorama 83-84, 2010, p. 50-79.

COUTO, Hildo Honório do. Alguns precursores da linguística ecossistêmica, 2014a. Disponível em: http://meioambienteelinguagem.blogspot.com.br/2014/06/ alguns-precursores-da-linguistica.html (05/02/2016). 
COUTO, Hildo Honório do. A concordância e a função comunicativa da linguagem: uma visão ecolinguística. Confluência 46, 2014b, p. 43-77. Disponível em: http://lp.bibliopolis.info/confluencia/rc/index.php/rc/article/view/7 Acesso: $05 / 11 / 2015$.

COUTO, Hildo Honório do. Linguística ecossistêmica. Ecolinguística: Revista brasileira de ecologia e linguagem (ECO-REBEL) v. 1, n. 1, 2015, p. 37-62. Disponível em: http://periodicos.unb.br/index.php/erbel/index (acesso: 05/02/2016).

COUTO, H. H.; COUTO, E. K.K.; ARAÚJO, G.; ALBUQUERQUE, D. (Orgs.). O paradigma ecológico nas ciências da linguagem: Ensaios ecolinguísticos clássicos e contemporâneos. Goiânia: Editora da UFG, 2016.

DEULEUZE, Gilles \& GUATTARI, Felix. 2000. Mil platôs: Capitalismo e esquizofrenia. Vol I. São Paulo: Editora 34, 2000, 1ed., $2^{\mathrm{a}}$ reimpressão.

FILL, Alwin (org.). Ökolinguistik: Eine Einführung. Tübingen: Gunter Narr, 1993.

FILL, Alwin. Sprachökologie und Ökolinguistik. Tübingen: Stauffenburg, 1996. FINKE, Peter. Sprache als missing link zwischen natürlichen und kulturellen Ökosystemen. In: Fill (org.), p. 27-48, 1996.

GARNER, Mark. Language: An ecological view. Berna: Peter Lang, 2004.

Haugen, Einar. The ecology of language. Stanford: Stanford University Press, 1972, p. 325-339.

HAUSER, Marc D.; CHOMSKY, Noam; FITCH, W. Tecumseh. The faculty of language: What is it, who has it, and how did it evolve? Science v. 298, 2002, p. 1569-1579.

LAMB, Sydney M. Outline of stratificational grammar. Washington, D.C.: Georgetown University Press, 1966.

FILL, Alwin. Pathways of the brain. Amsterdam: Benjamins, 1999.

FILL, Alwin. Neuro-cognitive structure in the interplay of language and thought. In: PÜTZ, Martin; VESPOOR, Marjolijn H. (orgs.) Explorations in linguistic relativity. Amsterdam: Benjamins, 2000, p. 173-196.

LEPSCHY, Giulio C. Linguística estrutural. São Paulo: Perspectiva, 1972.

MAKKAI, Adam. Ecolinguistics: ¿Toward a new **paradigm** for the science of language? Londres: Pinter Publishers, 1993. 
MORIN, Edgar. L'An I de l'ère écologique. Paris: Tallandier, 2007.

MORIN, Edgar. O método: A vida da vida. Porto Alegre: Editora Sulina, 2002, 2ed.

MUFWENE, Salikoko. Ecology of language evolution. Cambridge: Cambridge University Press, 2001.

MUFWENE, Salikoko. Language evolution: Contact, competition and change. Londres: Continuum, 2008.

OLIVEIRA, Marco Antônio. A variação fonológica na perspectiva da linguagem como um sistema adaptativo complexo. In: MAGALHÃES, José Sueli (Org.). Gramática comparada e geral: Fonologia. Uberlândia: EDUFU, 2014, p. 11-35. OLIVEIRA, Marco Antônio. Por uma abordagem etológica e ecológica da variação linguística. In: PARREIRA, Maria C. et al. (Oorgs.). Pesquisas em linguística no século XXI: Perspectivas e desafios teórico-metodológicos. São Paulo: Cultura Acadêmica, 2015, p. 45-70 (Série Trilhas Linguísticas, 27).

MADEIRA, Angélica. Raízes e Rizomas do Brasil. Caderno do IPRI n. 15, 1994, p. 23-31.

PIATELLI-PALMARINI; URIAGEREKA, Juan. The immune syntax: The evolution of the languag virus. In: JENKINS, Lyle (org.). Variation and universals in biolinguistics. Amsterdam: Elsevier, 2004, p. 341-377.

PINKER, Steven; JACKENDOFF, Ray. The faculty of language: what's special about it? Cognititon 95, 2005, p. 201-236.

TRAMPE, Wilhelm. Ökologische Linguistik: Grundlagen einer ökologischen Wissenschafts- und Sprachtheorie. Opladen: Westdeutscher Verlag, 1990.

Submetido: $14 / 04 / 2016$

Aceite: 14/07/2016 